\title{
ESL learners' online research and comprehension strategies
}

\author{
Noridah Sain ${ }^{1}$, Andy Bown ${ }^{2}$, Andrew Fluck ${ }^{3}$, and Paul Kebble ${ }^{4}$
}

\begin{abstract}
In order to enhance second language (L2) acquisition, English as a Second Language (ESL) students are encouraged to exploit the abundant information and opportunities for authentic language use afforded by the Internet. This study investigated the online research and comprehension strategies employed by ESL learners in a public university in Malaysia. The study was descriptive and the data was collected via the Qualtrics survey system. Data analysis demonstrated the most and least frequently used online research and comprehension strategies of $74 \mathrm{ESL}$ undergraduates and uncovered an overview of the ESL undergraduates' existing online research and comprehension strategies. The findings suggest that explicit training in the area of online research and comprehension processes is worth pursuing in the development of online study skills. This study also presents validation of a survey instrument used within the study to assess ESL learners' online research and comprehension strategies.
\end{abstract}

Keywords: online research strategies, digital literacies, ESL learners, Asia.

\section{Introduction}

The Internet has become an important, if not indispensable, tool for communication, information retrieval, transaction processing, and problem solving in all aspects of our lives. In classroom contexts, learners today rely heavily on the Internet as a source of information, rendering the ability to comprehend what is read during online research and learning even more crucial to knowledge-based societies (Goldman et al., 2012). "The plethora of information available online, coupled

\footnotetext{
1. University of Tasmania, Launceston, Australia; noridah.sain@utas.edu.au

2. University of Tasmania, Launceston, Australia; andy.bown@utas.edu.au

3. University of Tasmania, Launceston, Australia; andrew.fluck@utas.edu.au

4. University of Tasmania, Launceston, Australia; paul.kebble@utas.edu.au

How to cite this article: Sain, N., Bown, A., Fluck, A., \& Kebble, P. (2017). ESL learners' online research and comprehension strategies. In K. Borthwick, L. Bradley \& S. Thouësny (Eds), CALL in a climate of change: adapting to turbulent global conditions - short papers from EUROCALL 2017 (pp. 271-276). Research-publishing.net. https://doi.org/10.14705/rpnet.2017. eurocall2017.725
} 
with heavy reliance on the Internet by information seekers raise issues of the credibility or quality of information found online" (Metzger, 2007).

To make effective use of new technologies in their academic and future endeavors, Malaysian undergraduates need to be aware of the skills required to autonomously use the Internet for academic purposes. Located within the ESL context in a public university in Malaysia, this study aimed to explore the use of the Internet when undergraduates conduct online research and comprehension activities in order to provide practitioners with data about the use of the Internet to better assist their students.

\section{Method}

Seventy-four undergraduates (21 male and 53 female) from a public university in Malaysia were identified using convenience sampling to participate in this study. They were around the age of 19 to 21 years old. These 74 students were second and third semester ESL students from various courses.

The instrument developed for this study is the Online Research And Comprehension Strategies (ORACS) survey. The ORACS survey consisted of 37 items. Sixteen items were based on the five processes involved in online research and comprehension activities suggested by the new literacies of online research and comprehension perspectives (Kingsley \& Tancock, 2014) while the other 21 items were taken from the Online Survey of Online Reading Strategies (OSORS) by Anderson (2003). OSORS made use of a five point Likert scale and each item in the ORACS survey used a similar scaling option. To date, OSORS (Anderson, 2003) has been widely used to assess students' strategies when reading online and comprehending online information.

However, this popular survey instrument lacks the navigational aspect, which is important in assessing online research and comprehension strategies. The ORACS survey instrument included the navigational aspect, which was missing in OSORS. The Cronbach's alpha for the ORACS was found to be .97. The survey was administered in a computer laboratory during a formal weekly meeting.

The ORACS survey link was uploaded to the e-learning platform used by the academic staff and students of the chosen public university. Prior to filling out the ORACS survey, participants were first led to the online informed consent on which they were required to indicate their willingness to participate in the study. 


\section{Results}

Table 1 summarizes the top five online research and comprehension strategies among the total 37 items in the ORACS survey.

Table 1. Five online research and comprehension strategies most frequently used by ESL undergraduates

\begin{tabular}{|c|c|c|c|c|c|c|c|}
\hline $\begin{array}{l}\text { Online Research } \\
\text { and Comprehension } \\
\text { Strategies }\end{array}$ & ¿̀ & 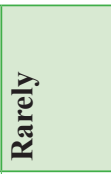 & 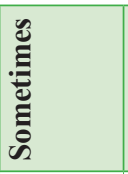 & อँ & 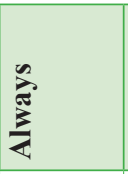 & 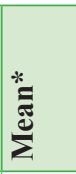 & 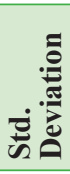 \\
\hline $\begin{array}{l}\text { I read the article } \\
\text { closely after I } \\
\text { have identified } \\
\text { specific information } \\
\text { within webpages } \\
\text { when conducting } \\
\text { online research. }\end{array}$ & 0 & $\begin{array}{l}6 \\
(8.1 \%)\end{array}$ & $\begin{array}{l}17 \\
(23.0 \%)\end{array}$ & $\begin{array}{l}40 \\
(54.1 \%)\end{array}$ & $\begin{array}{l}11 \\
(14.9 \%)\end{array}$ & 3.76 & .808 \\
\hline $\begin{array}{l}\text { I re-read online } \\
\text { text to increase } \\
\text { my understanding } \\
\text { when online text } \\
\text { becomes difficult. }\end{array}$ & $\begin{array}{l}1 \\
(1.4 \%)\end{array}$ & $\begin{array}{l}4 \\
(5.4 \%)\end{array}$ & $\begin{array}{l}20 \\
(27 \%)\end{array}$ & $\begin{array}{l}33 \\
(44.6 \%)\end{array}$ & $\begin{array}{l}16 \\
(21.6 \%)\end{array}$ & 3.80 & .891 \\
\hline $\begin{array}{l}\text { Online Research } \\
\text { and Comprehension } \\
\text { Strategies }\end{array}$ & ż & 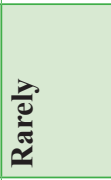 & 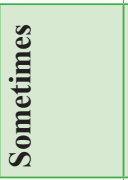 & อี & 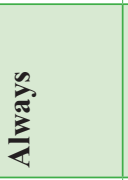 & 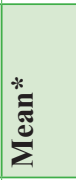 & 这 \\
\hline $\begin{array}{l}\text { I use reference } \\
\text { material (e.g. an } \\
\text { online dictionary) to } \\
\text { help me understand } \\
\text { what I read online. }\end{array}$ & $\begin{array}{l}1 \\
(1.4 \%)\end{array}$ & $\begin{array}{l}2 \\
(2.7 \%)\end{array}$ & $\begin{array}{l}23 \\
(31.1 \%)\end{array}$ & $\begin{array}{l}23 \\
(31.1 \%)\end{array}$ & $\begin{array}{l}25 \\
(33.8 \%)\end{array}$ & 3.93 & .941 \\
\hline $\begin{array}{l}\text { I use keyword } \\
\text { search and phrase } \\
\text { searching strategies } \\
\text { when conducting } \\
\text { online research. }\end{array}$ & 0 & $\begin{array}{l}3 \\
(4.1 \%)\end{array}$ & $\begin{array}{l}24 \\
(32.4 \%)\end{array}$ & $\begin{array}{l}35 \\
(47.3 \%)\end{array}$ & $\begin{array}{l}12 \\
(16.2 \%)\end{array}$ & 3.76 & .773 \\
\hline $\begin{array}{l}\text { I click on links or } \\
\text { hyperlinks that are } \\
\text { useful for my task } \\
\text { within webpages } \\
\text { that I find when } \\
\text { conducting online } \\
\text { research. }\end{array}$ & 0 & $\begin{array}{l}5 \\
(6.8 \%)\end{array}$ & $\begin{array}{l}23 \\
(31.1 \%)\end{array}$ & $\begin{array}{l}35 \\
(47.3 \%)\end{array}$ & $\begin{array}{l}11 \\
(14.9 \%)\end{array}$ & 3.70 & .806 \\
\hline
\end{tabular}

*Never $=1$, Rarely $=2$, Sometimes $=3$, Often $=4$, Always $=5$ 
Table 2 lists the five online research and comprehension strategies that the ESL undergraduates would use the least when conducting online research based on the ORACS survey.

Table 2. Five least frequently used online research and comprehension strategies by ESL undergraduates

\begin{tabular}{|c|c|c|c|c|c|c|c|}
\hline $\begin{array}{l}\text { Online } \\
\text { Research and } \\
\text { Comprehension } \\
\text { Strategies }\end{array}$ & $\frac{\dot{0}}{z^{\circ}}$ & 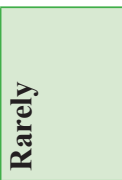 & 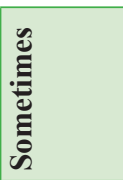 & एँ & $\sum_{\substack{i \\
\psi}}^{\infty}$ & $\stackrel{\text { * }}{\stackrel{*}{\Xi}}$ & 窇 \\
\hline $\begin{array}{l}\text { I differentiate the } \\
\text { author's tone and } \\
\text { purpose in the } \\
\text { sources that I find } \\
\text { on the Internet } \\
\text { when conducting } \\
\text { online research. }\end{array}$ & 0 & $\begin{array}{l}8 \\
(10.8 \%)\end{array}$ & $\begin{array}{l}41 \\
(55.4 \%)\end{array}$ & $\begin{array}{l}19 \\
(25.7 \%)\end{array}$ & $\begin{array}{l}6 \\
(8.1 \%)\end{array}$ & 3.31 & .775 \\
\hline $\begin{array}{l}\text { I use Google } \\
\text { Scholar when } \\
\text { conducting online } \\
\text { research. }\end{array}$ & $\begin{array}{l}8 \\
(10.8 \%)\end{array}$ & $\begin{array}{l}18 \\
(24.3 \%)\end{array}$ & \begin{tabular}{|l|}
22 \\
$(29.7 \%)$
\end{tabular} & $\begin{array}{l}17 \\
(23.0 \%)\end{array}$ & $\begin{array}{l}9 \\
(12.2 \%)\end{array}$ & 3.01 & 1.19 \\
\hline $\begin{array}{l}\text { I use Google } \\
\text { Advanced Search or } \\
\text { Yahoo! Advanced } \\
\text { Web Search to } \\
\text { narrow down my } \\
\text { search results } \\
\text { when conducting } \\
\text { online research. }\end{array}$ & $\begin{array}{l}3 \\
(4.1 \%)\end{array}$ & $\begin{array}{l}18 \\
(24.3 \%)\end{array}$ & \begin{tabular}{|l}
26 \\
$(35.1 \%)$
\end{tabular} & $\begin{array}{l}14 \\
(18.9 \%)\end{array}$ & $\begin{array}{l}13 \\
(17.6 \%)\end{array}$ & 3.22 & 1.13 \\
\hline $\begin{array}{l}\text { I print out a hard } \\
\text { copy of the online } \\
\text { text then underline } \\
\text { or circle the } \\
\text { information to help } \\
\text { me remember it. }\end{array}$ & $\begin{array}{l}1 \\
(1.4 \%)\end{array}$ & $\begin{array}{l}21 \\
(28.4 \%)\end{array}$ & \begin{tabular}{|l|}
21 \\
$(28.4 \%)$
\end{tabular} & \begin{tabular}{|l|}
21 \\
$(28.4 \%)$
\end{tabular} & $\begin{array}{l}10 \\
(13.5 \%)\end{array}$ & 3.24 & 1.06 \\
\hline $\begin{array}{l}\text { Online } \\
\text { Research and } \\
\text { Comprehension } \\
\text { Strategies }\end{array}$ & $\frac{\dot{d}}{\grave{z}}$ & 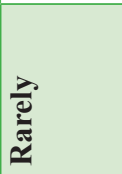 & 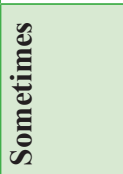 & 坖 & 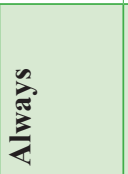 & $\stackrel{*}{\Xi}$ & 这 \\
\hline $\begin{array}{l}\text { I read aloud to help } \\
\text { me understand } \\
\text { what I read } \\
\text { when online text } \\
\text { becomes difficult. }\end{array}$ & $\begin{array}{l}4 \\
(5.4 \%)\end{array}$ & $\begin{array}{l}16 \\
(21.6 \%)\end{array}$ & \begin{tabular}{|l|}
23 \\
$(31.1 \%)$
\end{tabular} & $\begin{array}{l}21 \\
(28.4 \%)\end{array}$ & $\begin{array}{l}10 \\
(13.5 \%)\end{array}$ & 3.23 & 1.11 \\
\hline
\end{tabular}

*Never $=1$, Rarely $=2$, Sometimes $=3$, Often $=4$, Always $=5$ 


\section{Discussion}

The results from this study revealed that the ESL undergraduates would often or always use strategies that help them understand the online information when conducting online research. They do this by reading carefully, re-reading, and using online tools such as an online dictionary when trying to comprehend the online information. They would also often or always use keyword and phrase searching strategies followed by clicking on links or hyperlinks that they perceived to be useful for their task within the webpages that they found when conducting online research. These strategies are related to one of the five processing practices that occur during online research and comprehension activity: locating online information. The other four processing practices are defining important questions, evaluating online information, synthesizing online information, and communicating online information (Kingsley \& Tancock, 2014). From Table 2, it is found that one of the strategies that these ESL undergraduates would rarely or never use is connected to the practice of evaluating online information (differentiating the author's tone and purpose in online sources). Such low frequencies of the practice of critically evaluating online information imply that the participants lack awareness with regard to the issue of reliability and credibility of online information. Other less frequently used strategies point to the participants' insufficient exposure to several online tools (Google Scholar, Google Advanced Search, and Yahoo! Advanced Web Search) that may assist them in locating online information more effectively during online research. Overall, the findings showed that the ESL undergraduates did not use all of the strategies investigated in the ORACS survey and the way they used the strategies was centered on a particular, or presumably, limited number of strategies.

\section{Conclusion}

The findings from this research substantiate the growing concern among educators about the ability of current students to successfully conduct online research and critically evaluate online information sources for academic purposes (Sain, Md. Nawi, Mustafa, \& Kadir, 2014). However, the small sample size obtained from a single university limits the external validity of this study. Future research should also compare the students' self-reported strategies with their actual online research and comprehension performance. Nevertheless, it is hoped that the findings from this research will further assist language practitioners and policymakers to put forward approaches to boost the online research and comprehension skills among students in Malaysia so that these students may utilize their skills and strategies for their future needs. 


\section{Acknowledgements}

This work was supported by the University of Tasmania, Australia.

\section{References}

Anderson, N. (2003). Scrolling, clicking, and reading English: online reading strategies in a second/foreign language. The Reading Matrix, 3(3), 1-33. http://citeseerx.ist.psu.edu/ viewdoc/download?doi=10.1.1.110.2782\&rep=rep1\&type=pdf

Goldman, S. R., Braasch, J. L. G., Wiley, J., Graesser, A. C., \& Brodowinska, K. (2012). Comprehending and learning from internet sources: processing patterns of better and poorer learners. Reading Research Quarterly, 47(4), 356-381.

Kingsley, T., \& Tancock, S. (2014). Internet inquiry. The Reading Teacher, 67(5), 389-399. https://doi.org/10.1002/trtr.1223

Metzger, M. J. (2007). Making sense of credibility on the web: models for evaluating online information and recommendations for future research. Journal of the American Society for Information Science and Technology, 58(13), 2078-2091. https://doi.org/10.1002/asi.20672

Sain, N., Md. Nawi, S., Mustafa, H., Kadir, H. (2014). Investigating the needs for innovative online-based research practices in the ESL classrooms. In C. Fook et al. (Eds). 7th International Conference on University Learning and Teaching (InCULT 2014) Proceedings. Springer. https://doi.org/10.1007/978-981-287-664-5 52 


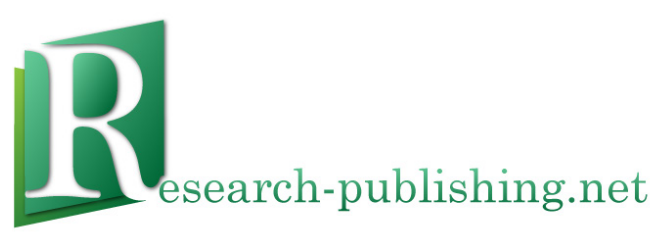

Published by Research-publishing.net, not-for-profit association Contact: info@research-publishing.net

(C) 2017 by Editors (collective work)

(C) 2017 by Authors (individual work)

CALL in a climate of change: adapting to turbulent global conditions - short papers from EUROCALL 2017 Edited by Kate Borthwick, Linda Bradley, and Sylvie Thouësny

Rights: This volume is published under the Attribution-NonCommercial-NoDerivatives International (CC BY-NC-ND) licence; individual articles may have a different licence. Under the CC BY-NC-ND licence, the volume is freely available online (https://doi.org/10.14705/rpnet.2017.eurocall2017.9782490057047) for anybody to read, download, copy, and redistribute provided that the author(s), editorial team, and publisher are properly cited. Commercial use and derivative works are, however, not permitted.

Disclaimer: Research-publishing.net does not take any responsibility for the content of the pages written by the authors of this book. The authors have recognised that the work described was not published before, or that it was not under consideration for publication elsewhere. While the information in this book are believed to be true and accurate on the date of its going to press, neither the editorial team, nor the publisher can accept any legal responsibility for any errors or omissions that may be made. The publisher makes no warranty, expressed or implied, with respect to the material contained herein. While Research-publishing.net is committed to publishing works of integrity, the words are the authors' alone.

Trademark notice: product or corporate names may be trademarks or registered trademarks, and are used only for identification and explanation without intent to infringe.

Copyrighted material: every effort has been made by the editorial team to trace copyright holders and to obtain their permission for the use of copyrighted material in this book. In the event of errors or omissions, please notify the publisher of any corrections that will need to be incorporated in future editions of this book.

Typeset by Research-publishing.net

Cover design based on (C) Josef Brett's, Multimedia Developer, Digital Learning, http://www.eurocall2017.uk/, reproduced with kind permissions from the copyright holder.

Cover layout by (C) Raphaël Savina (raphael@savina.net)

Photo "frog” on cover by (C) Raphaël Savina (raphael@savina.net)

Fonts used are licensed under a SIL Open Font License

ISBN13: 978-2-490057-04-7 (Ebook, PDF, colour)

ISBN13: 978-2-490057-05-4 (Ebook, EPUB, colour)

ISBN13: 978-2-490057-03-0 (Paperback - Print on demand, black and white)

Print on demand technology is a high-quality, innovative and ecological printing method; with which the book is never 'out of stock' or 'out of print'.

British Library Cataloguing-in-Publication Data.

A cataloguing record for this book is available from the British Library.

Legal deposit: Bibliothèque Nationale de France - Dépôt légal: décembre 2017. 